\title{
Epidemiological profile of suicide in the Santa Catarina Coal Mining Region from 1980 to 2007
}

\author{
Perfil epidemiológico do suicídio na Região Carbonífera \\ Catarinense de 1980 a 2007
}

Carolina H. Portella, ${ }^{1}$ Gustavo P. Moretti, ${ }^{1}$ Ana P. Panatto, ${ }^{1}$ Maria I. Rosa, ${ }^{1}$ João Quevedo, ${ }^{2}$ Priscyla W. T. A. Simões ${ }^{1}$

\begin{abstract}
Background: Suicide is a public health problem worldwide. Estimates have indicated that over 1 million people commit suicide every year all over the world. Brazil has a moderate suicide death rate (4.1 per 100,000 inhabitants), but the fact that it is a large country leads to the coexistence of diverse characteristics and levels of development across the different Brazilian regions. In this sense, the South region has been shown to present suicide rates above the national average.

Objective: To estimate the profile of suicide in municipalities comprising the Santa Catarina Coal Mining Region from 1980 to 2007.

Methods: This ecological, time-series, descriptive study sought to characterize epidemiological aspects related to suicide method, marital status, sex, age, and occupation in the municipalities of the region in the years 1980 to 2007.

Results: A total of 474 suicides occurred in the period, yielding a mean death rate of 10.83 per 100,000 inhabitants. There was a predominance of males, at a $5: 1$ ratio, and a peak rate in the 5564 -year age group (11.31 per 100,000 inhabitants). The suicide method most commonly used was hanging $(72 \%)$ and the most frequent occupation was hard labor work $(11.60 \%)$; in relation to marital status, married subjects $(48 \%)$ were the ones with the highest rates of suicide.

Conclusions: The Santa Catarina Coal Mining Region has suicide mortality rates above the national average. This study highlights specific characteristics of suicide in the region and may contribute to the development of preventive measures.
\end{abstract}

Keywords: Suicide, epidemiology, southern Brazil.

\section{Resumo}

Introdução: O suicídio é um problema mundial de saúde pública. Estimativas apontam que, anualmente, mais de 1 milhão de pessoas cometem suicídio em todo o mundo. O Brasil possui um coeficiente mediano de suicídio (4,1 por 100 mil habitantes), porém o fato de ser um país de grandes dimensões faz com que características e níveis de desenvolvimento variem grandemente em diferentes regiões. Nesse aspecto, o sul do país se destaca por possuir índices acima da média nacional.

Objetivos: Estimar o perfil do suicídio nos municípios da Região Carbonífera Catarinense no período de 1980 a 2007.

Metodologia: Estudo ecológico, temporal, descritivo, que buscou caracterizar os aspectos epidemiológicos em relação aos meios empregados para cometer suicídio, estado civil, gênero, faixa etária e ocupação nos municípios da região nos anos de 1980 a 2007.

Resultados: Ocorreram 474 suicídios no período, o que gerou um coeficiente médio de 10,83 por 100.000 habitantes. Houve predomínio masculino, na proporção de 5:1, e pico na faixa etária entre 55 e 64 anos (11,31 por 100.000 habitantes). O meio mais utilizado foi o enforcamento (72\%), e a ocupação mais frequente foi a dos trabalhadores braçais $(11,60 \%)$; em relação ao estado civil, os casados foram os que mais cometeram suicídio (48\%).

Conclusão: A Região Carbonífera Catarinense apresenta coeficientes de mortalidade por suicídio acima da média nacional. O presente estudo destaca características próprias do suicídio na região, podendo contribuir para o desenvolvimento de ações preventivas.

Descritores: Suicídio, epidemiologia, sul do Brasil.

\footnotetext{
${ }^{1}$ Laboratório de Epidemiologia, Programa de Pós-Graduação em Ciências da Saúde, Unidade Acadêmica de Ciências da Saúde, Universidade do Extremo Sul Catarinense, Criciúma, SC, Brazil. National Science and Technology Institute for Translational Medicine (INCT-TM). ${ }^{2}$ Laboratório de Neurociências, Programa de PósGraduação em Ciências da Saúde, Unidade Acadêmica de Ciências da Saúde, Universidade do Extremo Sul Catarinense, Criciúma, SC, Brazil. INCT-TM.

This paper is based on the first author's final monograph, presented at the School of Medicine of Universidade do Extremo Sul Catarinense in the first semester of 2010. An abstract of the manuscript has been presented at a science internship conference held at the same university in the second semester of 2010.

Financial support: none.

Submitted Mar 07 2012, accepted for publication Sep 26 2012. No conflicts of interest declared concerning the publication of this article.

Suggested citation: Portella CH, Moretti GP, Panatto AP, Rosa MI, Quevedo J, Simões PW. Epidemiological profile of suicide in the Santa Catarina Coal Mining Region from 1980 to 2007. Trends Psychiatry Psychother. 2012;35(2):128-33.
} 


\section{Introduction}

Early statistical data on suicide date back to the 19th century, published by French sociologist Emile Durkheim. ${ }^{1}$ The mortality rate for suicide in Brazil has been estimated at 4.1 per 100,000 inhabitants for the general population, ranging from about 1.8 among females to 6.6 among males. ${ }^{2}$ These rates are among the lowest ones reported worldwide, especially when compared with European countries, where suicide rates reach over 40 deaths per 100,000 inhabitants. ${ }^{3}$

Between 1980 and 2006, a 29.5\% increase was observed in the number of suicides in Brazil. ${ }^{4}$ Higher mean rates have been observed in the South ( 9.3 per 100,000 inhabitants) and Central West regions (6.1 per 100,000 inhabitants). The southern municipalities of Porto Alegre (7.3 per 100,000 inhabitants) and Florianópolis (6.5 per 100,000 inhabitants) ranked second and third, respectively, among all state capitals. ${ }^{4}$

The term suicide derives from the Latin expression sui caedere, which means to kill oneself, and was first used in 1717 by Desfontaines. Sometimes referred to as voluntary death, intentional death, or self-inflicted death, suicide means a deliberate, intended act committed by an individual and resulting in his/her own death. ${ }^{5}$ For Durkheim, suicide is applied to all cases of death resulting directly or indirectly from a positive or negative act of the victim him/herself, which he knows will produce this result. ${ }^{1}$

Suicide is a public health problem, with underestimated effects due to the limited number of studies assessing Brazilian and international statistic data on suicide rates. Estimates from the World Health Organization (WHO) have shown that over 1 million people commit suicide every year worldwide, making this phenomenon rank third among main causes of death in people aged 15 to 44 years. ${ }^{6}$

According to the literature, in most countries there is a predominance of males among people who commit suicide, at a mean male to female ratio of $3: 1$, even though this ratio may change in different countries. ${ }^{7}$ Conversely, women are four times more common among suicide attempters than men. These results may be explained by the fact that men use more aggressive and potentially lethal methods in their suicide attempts (e.g., firearms and hanging) when compared with women. ${ }^{7}$ China is the only country where suicide rates among women are higher than among men, in rural areas; in urban areas, rates are approximately the same. These differences are believed to be associated with socially determined behaviors. ${ }^{8,9}$

Suicide is among the five main causes of death in the 15-19-year age group worldwide, especially among males. Moreover, an increased risk for suicide has been reported for elderly people (aged over 65 years) and young adults (15 to 30 years). Recent data have suggested an increase in suicide rates among middle-aged men. ${ }^{10}$

The objective of the present study was to estimate the epidemiological profile of suicide in the municipalities comprising the Santa Catarina Coal Mining Region between 1980 and 2007, with emphasis on suicide method, marital status, sex, age group, and occupation.

\section{Methods}

This ecological, time-series, descriptive study was approved by the Research Ethics Committee of Universidade do Extremo Sul Catarinense (protocol no. 175/2009). The following variables were assessed: suicide method, marital status, sex, age group, and occupation.

The study population comprised all cases of suicide occurring in the municipalities of the Santa Catarina Coal Mining Region. This region was chosen for being know to present high rates of mortality for suicide and because of its favorable location.

The Santa Catarina Coal Mining Region is a microregion located in the southeast area of the state of Santa Catarina. According to the Brazilian Institute of Geography and Statistics (IBGE), this region has a population of 384,577 inhabitants and comprises the municipalities of Cocal do Sul, Criciúma, Forquilhinha, Içara, Lauro Muller, Morro da Fumaça, Nova Veneza, Orleans, Siderópolis, Treviso, and Urussanga. The region's economy has been based on the extraction of coal over the past few decades, which explains the name given to the microregion. In the 1960s and 1970s, the region experienced industrial diversification and started to manufacture ceramics, clothing, food, shoes, construction, plastic, and metal-mechanic products. At present, the main activities in the region are clothing, plastic, ceramic, and metal mechanic industries. ${ }^{11}$

Time-series analyses were conducted for the period ranging from 1980 to 2007, for which death data were available at the Brazilian Mortality Information System (Sistema de Informações sobre Mortalidade, SIM) and at IBGE, both through the Information Technology Department of the Brazilian Unified Health System (DATASUS; www.datasus.gov.br).

Age was stratified according to age groups defined by the WHO, namely, 5-14, 15-24, 25-34, 35-44, 45$54,55-64$, and $65-74$ years. Occupation was categorized according to the Brazilian Classification of Occupations (Classificação Brasileira de Ocupações, CBO-2002), also used at SIM. ${ }^{12}$ In an attempt to standardize occupation categories, farming workers and hard labor workers were grouped in the same category, as were housewives/ 
househusbands and other domestic workers, and cases in which occupation was not informed or ignored.

Crude death rate was calculated by dividing the number of deaths by the population living in the area in the same period and multiplying it by 100,000 . Proportional and standardized ratios were calculated according to sex, age group, suicide method, and municipality with data available on both SIM and IBGE. For occupation and marital status, population data were lacking, and therefore only the proportional ratio was calculated.

Data related to each of the variables above were searched on the DATASUS and/or IBGE databases. The number of suicide cases occurring from 1980 to 1995 was calculated using the Ninth Revision of the International Classification of Diseases (ICD-9), ${ }^{13}$ which includes the following categories:

- E950 - Suicide and self-inflicted poisoning by solid or liquid substances;

- E951 - Suicide and self-inflicted poisoning by gases in domestic use;

- E952 - Suicide and self-inflicted poisoning by other gases and vapors;

- E953 - Suicide and self-inflicted injury by hanging, strangulation, and suffocation;

- E954 - Suicide and self-inflicted injury by submersion (drowning);

- E955 - Suicide and self-inflicted injury by firearms, air guns, and explosives;

- E956 - Suicide and self-inflicted injury by cutting and piercing instrument;

- E957 - Suicide and self-inflicted injuries by jumping from high place;

- E958 - Suicide and self-inflicted injury by other and unspecified means;

- E959 - Late effects of self-inflicted injury.

For the subsequent period, from 1996 to 2007, the Tenth Revision of the ICD (ICD-10) ${ }^{14}$ was used, including categories $X 60$ to $X 84$, which cover intentional self-inflicted harm, and Y87.0, which accounts for sequelae of selfinflicted harm. Categories X60 to X84 are described below:

- X60 - Intentional self-poisoning by and exposure to nonopioid analgesics, antipyretics, and antirheumatics;

- X61 - Intentional self-poisoning by and exposure to antiepileptic, sedative-hypnotic, antiparkinsonism, and psychotropic drugs not elsewhere classified;

- X62 - Intentional self-poisoning by and exposure to narcotics and psychodysleptics (hallucinogens) not elsewhere classified;

- X63 - Intentional self-poisoning by and exposure to other drugs acting on the autonomic nervous system;

- X64 - Intentional self-poisoning by and exposure to other and unspecified drugs, medicaments, and biological substances;
- X65 - Intentional self-poisoning by and exposure to alcohol;

- X66 - Intentional self-poisoning by and exposure to organic solvents and halogenated hydrocarbons and their vapors;

- X67 - Intentional self-poisoning by and exposure to other gases and vapors;

- X68 - Intentional self-poisoning by and exposure to pesticides;

- X69 - Intentional self-poisoning by and exposure to other and unspecified chemicals and noxious substances;

- X70 - Intentional self-harm by hanging, strangulation, and suffocation;

- X71 - Intentional self-harm by drowning and submersion;

- X72 - Intentional self-harm by handgun discharge;

- X73 - Intentional self-harm by rifle, shotgun, and larger firearm discharge;

- X74 - Intentional self-harm by other and unspecified firearm discharge;

- X75 - Intentional self-harm by explosive material;

- X76 - Intentional self-harm by smoke, fire, and flames;

- X77 - Intentional self-harm by steam, hot vapors, and hot objects;

- X78 - Intentional self-harm by sharp object;

- X79 - Intentional self-harm by blunt object;

- X80 - Intentional self-harm by jumping from a high place;

- X81 - Intentional self-harm by jumping or lying before moving object;

- X82 - Intentional self-harm by crashing of motor vehicle;

- X83 - Intentional self-harm by other specified means;

- X84 - Intentional self-harm by unspecified means.

Because of the differences between the two ICD versions, similar forms of self-harm were grouped together. For example, hanging included categories E953 from ICD-9 and X70 from ICD-10, firearm included categories E955 and X72-75, etc.

Data were accessed and analyzed using Tabnet and Tabwin software version 3.6. Descriptive analysis was conducted using Excel ${ }^{\circledR}$ version 2007.

\section{Results}

From 1980 to 2007, a total of 474 suicide deaths occurred in the municipalities of the Santa Catarina Coal Mining Region. The mean crude death rate over the period assessed was 10.83 per 100,000 inhabitants (Table 1 ).

Forquilhinha showed the lowest (6.17 per 100,000 inhabitants) and Nova Veneza the highest (15.37 per 
100,000 inhabitants) suicide rates over the period assessed. Of the 28 years analyzed, 2007 showed the peak rate (31.35 per 100,000 in habitants); the lowest rate was found in 1985 (1.02 per 100,000 inhabitants).

Mean suicide death rate among males increased from 6.4 in 1980 to 13.6 per 100,000 inhabitants in 2007 , adding it up to a $112.5 \%$ increase; among females, mean death rate increased from 1.8 to 2.1 per 100,000 inhabitants in the same years, at an increase of $11.66 \%$. Comparison of the rates observed for the two sexes suggests a male to female ratio of $4: 1$ in 1980 and of $6: 1$ in 2007 .

With regard to age group, a progressive increase was observed in the mean number of death rates in the first younger age groups. The highest mean rate was found in the 55-64-year age group, namely, 13.9 per 100,000 inhabitants. When analyzed according to age group and sex, the same age group was the one with the highest mean death rate among males, at 11.31 per 100,000 inhabitants. Among females, in turn, the highest rate was observed in the 65-74-year age group, namely, 2.55 per

Table 1 - Mean mortality rates for suicide in the municipalities of the Santa Catarina Coal Mining Region between 1980 and 2007

\begin{tabular}{lcc}
\hline Municipality & $\begin{array}{c}\text { Rate per 100,000 } \\
\text { inhabitants }\end{array}$ & $\begin{array}{c}\text { No. of } \\
\text { deaths }\end{array}$ \\
\hline Cocal do Sul & 6.84 & 13 \\
Criciúma & 10.53 & 224 \\
Forquilhinha & 6.17 & 15 \\
Içara & 7.52 & 47 \\
Lauro Muller & 12.57 & 24 \\
Morro da Fumaça & 14.14 & 24 \\
Nova Veneza & 15.37 & 24 \\
Orleans & 13.42 & 38 \\
Siderópolis & 9.27 & 17 \\
Treviso & 8.27 & 4 \\
Urussanga & 15.01 & 44 \\
Total & 10.83 & 474 \\
\hline
\end{tabular}

100,000 inhabitants (Table 2). A 20-fold increase was observed from 1980-1988 to 1999-2007 in the rate of suicide deaths in males aged 15 to 24 years, increasing from 0.32 to 6.89 , respectively (Table 2 ).

Analysis of the methods used to commit suicide showed that hanging was most commonly used, in $72 \%$ of the cases (category E953 on ICD-9 and X70 on ICD10). When men and women were analyzed independently, this was also the most frequent suicide method, accounting for 76 and $57 \%$ of deaths, respectively. The use of firearms ranked second, corresponding to $15 \%$ among males and $25 \%$ among females, followed by selfpoisoning in $5.5 \%$ of males and $9.3 \%$ of females.

Hard labor workers comprised the occupation group that most frequently committed suicide (11.6\%), followed by housewives/househusbands (10.5\%), who showed virtually the same rate as those for whom occupation was not informed (11.2\%).

With regard to marital status, married individuals were the ones who most frequently committed suicide $(48 \%)$, followed by single (35\%) and widowed subjects $(6.5 \%)$. A moderate positive correlation was observed among single subjects $(r=0.665)$, married $(r=0.448)$, and divorced ones $(r=0.551)$, suggesting an increase in the rate of suicides with time $(p<0.001)$. Proportional ratios for all the variables analyzed in the study are presented in Table 3.

\section{Discussion}

The highest mean mortality rates for suicide were found among subjects aged 55 to 64 years (13.9 per 100,000 inhabitants). Notwithstanding, in absolute numbers, suicide was more prevalent in the 35-44-year

Table 2 - Mortality rates for suicide according to age group and sex

\begin{tabular}{|c|c|c|c|c|c|c|}
\hline \multirow{2}{*}{$\begin{array}{l}\text { Sex/age group } \\
\text { (years) }\end{array}$} & \multicolumn{2}{|c|}{ 1980-1988 } & \multicolumn{2}{|c|}{ 1989-1998 } & \multicolumn{2}{|c|}{ 1999-2007 } \\
\hline & No. deaths* & Rate & No. deaths* & Rate & No. deaths* & Rate \\
\hline \multicolumn{7}{|l|}{ Male } \\
\hline $5-14$ & 0 & 0.00 & 2 & 0.33 & 1 & 0.17 \\
\hline $15-24$ & 16 & 0.32 & 26 & 5.05 & 38 & 6.89 \\
\hline $25-34$ & 13 & 3.27 & 37 & 7.00 & 35 & 7.39 \\
\hline $35-44$ & 11 & 4.42 & 32 & 8.73 & 40 & 8.79 \\
\hline $45-54$ & 10 & 6.42 & 13 & 6.30 & 27 & 9.16 \\
\hline $55-64$ & 6 & 7.15 & 24 & 18.14 & 18 & 11.10 \\
\hline $65-74$ & 1 & 2.13 & 9 & 12.54 & 8 & 8.26 \\
\hline \multicolumn{7}{|l|}{ Female } \\
\hline 5-14 & 0 & 0.00 & 4 & 0.65 & 0 & 0.00 \\
\hline $15-24$ & 3 & 0.61 & 2 & 0.38 & 4 & 0.71 \\
\hline $25-34$ & 6 & 1.49 & 7 & 1.35 & 8 & 1.72 \\
\hline $35-44$ & 4 & 1.99 & 10 & 2.41 & 17 & 3.66 \\
\hline $45-54$ & 4 & 2.64 & 5 & 2.30 & 3 & 1.04 \\
\hline $55-64$ & 3 & 3.26 & 4 & 2.93 & 3 & 1.93 \\
\hline $65-74$ & 1 & 1.65 & 2 & 2.60 & 4 & 4.14 \\
\hline
\end{tabular}

* Number of deaths per 100,000 inhabitants, standardized for sex and population in the period. 
Table 3 - Suicide profile in the population assessed

\begin{tabular}{|c|c|c|c|c|c|c|c|}
\hline \multirow[b]{2}{*}{ Variable } & \multicolumn{7}{|c|}{ Year, n (\%) } \\
\hline & $1980-83$ & 1984-87 & 1988-91 & 1992-95 & 1996-99 & 2000-03 & 2004-07 \\
\hline \multicolumn{8}{|l|}{ Municipality } \\
\hline Cocal do Sul & $0(0.00)$ & $0(0.00)$ & $0(0.00)$ & $1(0.21)$ & $6(1.26)$ & $3(0.63)$ & $3(0.63)$ \\
\hline Criciúma & $16(3.37)$ & $21(4.43)$ & $36(7.59)$ & $26(5.48)$ & $38(8.01)$ & $40(8.43)$ & $47(9.91)$ \\
\hline Forquilhinha & $0(0.00)$ & $0(0.00)$ & $3(0.63)$ & $2(0.42)$ & $3(0.63)$ & $2(0.42)$ & $5(1.05)$ \\
\hline Içara & $1(0.21)$ & $2(0.42)$ & $7(1.47)$ & $8(1.68)$ & $8(1.68)$ & $11(2.32)$ & $10(2.10)$ \\
\hline Lauro Muller & $1(0.21)$ & $0(0.00)$ & $5(1.05)$ & $2(0.42)$ & $3(0.63)$ & $8(1.68)$ & $5(1.05)$ \\
\hline Morro da Fumaça & $7(1.47)$ & $2(0.42)$ & $4(0.84)$ & $2(0.42)$ & $0(0.00)$ & $5(1.05)$ & $4(0.84)$ \\
\hline Nova Veneza & $0(0.00)$ & $2(0.42)$ & $5(1.05)$ & $3(0.63)$ & $4(0.84)$ & $6(1.26)$ & $4(0.84)$ \\
\hline Orleans & $2(0.42)$ & $2(0.42)$ & $7(1.47)$ & $5(1.05)$ & $6(1.26)$ & $5(1.05)$ & $11(2.32)$ \\
\hline Siderópolis & $1(0.21)$ & $1(0.21)$ & $2(0.42)$ & $5(1.05)$ & $1(0.21)$ & $2(0.42)$ & $5(1.05)$ \\
\hline Treviso & $0(0.00)$ & $0(0.00)$ & $0(0.00)$ & $0(0.00)$ & $0(0.00)$ & $2(0.42)$ & $2(0.42)$ \\
\hline Urussanga & $1(0.21)$ & $9(1.89)$ & $6(1.26)$ & $10(2.10)$ & $7(1.47)$ & $4(0.84)$ & $7(1.47)$ \\
\hline \multicolumn{8}{|l|}{ Age group (years) } \\
\hline $5-14$ & $0(0.00)$ & $0(0.00)$ & $2(0.42)$ & $3(0.63)$ & $2(0.42)$ & $0(0.00)$ & $0(0.00)$ \\
\hline $15-24$ & $7(1.47)$ & $10(2.10)$ & $11(2.32)$ & $10(2.10)$ & $11(2.32)$ & $17(3.58)$ & $23(4.85)$ \\
\hline $25-34$ & $5(1.05)$ & $9(1.89)$ & $22(4.64)$ & $17(3.58)$ & $15(3.16)$ & $16(3.37)$ & $22(4.64)$ \\
\hline $35-44$ & $3(0.63)$ & $10(2.10)$ & $17(3.58)$ & $13(2.74)$ & $20(4.21)$ & $26(5.48)$ & $25(5.27)$ \\
\hline $45-54$ & $5(1.05)$ & $8(1.68)$ & $6(1.26)$ & $7(1.47)$ & $8(1.68)$ & $15(3.16)$ & $13(2.74)$ \\
\hline $55-64$ & $8(1.68)$ & $1(0.21)$ & $10(2.10)$ & $8(1.68)$ & $12(2.53)$ & $8(1.68)$ & $11(2.32)$ \\
\hline $65-74$ & $1(0.21)$ & $0(0.00)$ & $5(1.05)$ & $5(1.05)$ & $3(0.63)$ & $3(0.63)$ & $8(1.68)$ \\
\hline \multicolumn{8}{|l|}{ Suicide method } \\
\hline Hanging & $20(4.21)$ & $27(5.69)$ & $52(10.97)$ & $46(9.70)$ & $56(11.81)$ & $67(14.13)$ & $74(15.61)$ \\
\hline Firearm & $4(0.84)$ & $7(1.47)$ & $19(4.00)$ & $15(3.16)$ & $13(2.74)$ & $15(3.16)$ & $7(1.47)$ \\
\hline Self poisoning & $0(0.00)$ & $3(0.63)$ & $3(0.63)$ & $2(0.42)$ & $4(0.84)$ & $3(0.63)$ & $15(3.16)$ \\
\hline \multicolumn{8}{|l|}{ Marital status } \\
\hline Single & $8(1.68)$ & $16(3.37)$ & $24(5.06)$ & $27(5.69)$ & $26(5.48)$ & $30(6.32)$ & $37(7.80)$ \\
\hline Marriage & $16(3.37)$ & $22(4.64)$ & $39(8.22)$ & $30(6.32)$ & $45(9.49)$ & $40(8.43)$ & $36(7.59)$ \\
\hline Widowed & $4(0.84)$ & $1(0.21)$ & $7(1.47)$ & $3(0.63)$ & $2(0.42)$ & $6(1.26)$ & $7(1.47)$ \\
\hline Divorced & $0(0.00)$ & $0(0.00)$ & $2(0.42)$ & $0(0.00)$ & $2(0.42)$ & $3(0.63)$ & $9(1.89)$ \\
\hline Other & $0(0.00)$ & $0(0.00)$ & $1(0.21)$ & $1(0.21)$ & $1(0.21)$ & $2(0.42)$ & $3(0.63)$ \\
\hline N/A & $1(0.21)$ & $0(0.00)$ & $2(0.42)$ & $3(0.63)$ & $0(0.00)$ & $6(1.26)$ & $11(2.32)$ \\
\hline \multicolumn{8}{|l|}{ Sex } \\
\hline Male & $23(4.85)$ & 27 (5.69) & $59(12.44)$ & 52 (10.97) & $64(13.50)$ & $72(15.18)$ & $82(17.29)$ \\
\hline Female & $6(1.26)$ & $12(2.53)$ & $16(3.37)$ & $12(2.53)$ & $12(2.53)$ & $16(3.37)$ & $21(4.43)$ \\
\hline
\end{tabular}

age group (71 cases). When stratified for sex, the 55-64year age group showed the highest mean rate of deaths among males (11.31 per 100,000 inhabitants), compared with the 65-74-year age group among females (2.55 per 100,000 inhabitants). Different values have been reported by similar studies conducted in other regions of the state of Santa Catarina. One of such studies analyzed suicide in the Metropolitan region of Florianópolis ${ }^{15}$ from 1991 to 2005 and found the highest absolute number of suicides in the 20-25-year age group (66.2\%). Another study, performed in the extreme west of the state ${ }^{16}$ and focusing on the period from 1980 to 2005, found the highest absolute values in the 20-39-year age group ( $n=101)$, even though mean death rates were progressively higher as age increased.

Despite the divergences found in the state of Santa Catarina, the results here reported for the state's Coal Mining Region are similar to rates described for most countries, with higher rates among the elderly. ${ }^{17-22}$ In this specific subpopulation, suicide seems to be associated with psychiatric disorders, especially depression. ${ }^{18}$ Diminished cognitive ability and physical agility, lack of independence, in addition to conditions that are inherent to the aging process, are important factors contributing to suicide as of the sixth decade of life. ${ }^{17,21}$ Notwithstanding, this pattern seems to be changing, and a gradual increase in suicide rates seems to be occurring among young adults, especially males, probably as a result of a higher frequency of psychoactive substance abuse, social stressors, and depressive disorders. ${ }^{23,24}$

Hanging was the method most commonly used to commit suicide $(72 \%)$, which is similar to the results reported for the west of the state $(70 \%)^{16}$ but higher than the Brazilian average (25\%). ${ }^{25,26}$ Also, hard labor workers accounted for $11.60 \%$ of suicide cases, followed by housewives/househusbands (10.54\%). A previous Brazilian study had already reported high means of suicide among hard labor workers (16.3 per 100,000 inhabitants), ${ }^{27}$ which may probably be explained by the precarious working conditions and the economic instability faced by these workers.

With regard to marital status, our study revealed that married subjects showed the highest rates of suicide 
$(48.10 \%)$, a finding that contrasts with the literature. In fact, for some authors, being married is a protective factor against suicide, as a result of the affective bonding and responsibility that married implies. ${ }^{28-30}$

Our study is biased in that no suicide data were available on SIM for females in the year 1982. This flaw may have been the result of an operational problem during data collection or entry into the system, or it could reflect the real absence of female suicides in that year. Therefore, in our analysis, we considered that there were zero suicides among females in the year 1982. Moreover, in the analysis of marital status and occupation, only the proportional ratio could be calculated, as IBGE did not reveal sufficient data for the calculation of standardized ratios for all years. Another possible limitation of our study is related to its design: this was an ecological study where the units of analysis were groups rather than individuals. Future studies should investigate the causes that may have led to the statistics here presented.

The true incidence of suicide may be underestimated worldwide as a result of the fact that this is a highly stigmatized phenomenon, surrounded by myths and taboos, and also due to the unavailability of adequate technical equipment to determine the precise cause of death, resulting in a large number of unspecified records. All these factors contribute to making suicide statistics strongly influenced by undernotification. ${ }^{31,32}$

Finally, the epidemiological characterization of suicide in the Santa Catarina Coal Mining Region points to peculiarities of the region, which are probably different from other regions in the same state and in other Brazilian states. Nevertheless, we strongly believe that the present findings can be used to guide the planning of future studies and development of healthcare interventions aimed at minimizing this public health problem, especially in a state showing one of the highest suicide rates in Brazil.

\section{References}

1. Durkheim E. O suicídio: estudo sociológico. Rio de Janeiro: Zahar; 1982

2. World Health Organization, Department of Mental Health. Prevention of suicidal behaviors: a task for all. In: Mental and behavioral disorders. Geneva: WHO; 2000.

3. Mello-Santos C, Bertolote JM, Wang YP. Epidemiology of suicide in Brazil (1980-2000): characterization of age and gender rates of suicide. Rev Bras Psiquiatria. 2005;27:131-4.

4. Lovisi GM, Santos SA, Legay L, Abelha L, Valencia E. Epidemiological analysis of suicide in Brazil from 1980 to 2006. Rev Bras Psiquiatr. 2009;31(supl. 2):S86-94.

5. Lopes-Cardoso A. O direito de morrer: suicídio e eutanásia. Mem Martins: Europa-América; 1986.

6. World Health Organization. The global burden of disease: 2004 update. Geneva: WHO; 2008. http://www.who.int/healthinfo/ global_burden_disease/2004_report_update/en/index.html. Accessed 2011 Nov.

7. Arantes-Gonçalves F, Coelho R. À procura de marcadores biológicos no comportamento suicidário. Acta Med Port. 2008;21:89-98.

8. Rapeli CB, Botega NJ. Severe suicide attempts in young adults: suicide intent is correlated with medical lethality. Sao Paulo Med J. $2005 ; 123: 43$.
9. Kaplan MS, Adamek ME, Martin JL. Confidence of primary care physicians in assessing the suicidality of geriatric patients. Int J Geriatr Psychiatry. 2001;16:728-34.

10. da Silva VF, de Oliveira HB, Botega NJ, Marín-León L, Barros MB, Dalgalarrondo P. Factors associated with suicidal ideation in the community: a case-control study. Cad Saude Publica. 2006;22:1835-43.

11. Secretaria de Estado da Saúde do Estado de Santa Catarina. Caderno de indicadores. http://portalses.saude.sc.gov.br/index. php?option=com_content\&view =article\&id=876\%3Amodelos-geralregioes-de-saude\&catid=378\&Itemid=294. Accessed 2012 Sep 18.

12. Brasil, Ministério do Trabalho e Emprego. Classificação brasileira de ocupações. 2002. http://www.mtecbo.gov.br/cbosite/pages/ home.jsf. Accessed 2012 Sep 18.

13. World Health Organization. International statistical classification of diseases, injuries, and causes of death. 9th ed. Geneva: WHO; 1975.

14. World Health Organization. International statistical classification of diseases, injuries, and causes of death. 10th ed. Geneva: WHO; 1992.

15. Kliemann DV. Estudo epidemiológico de óbitos por suicídio na região da grande Florianópolis de 1991 a 2005 [monograph]. Florianópolis: Universidade Federal de Santa Catarina; 2007.

16. Schmit R, Lang, MG, Quevedo J, Colombo T. Perfil epidemiológico do suicídio no extremo oeste do estado de Santa Catarina, Brasil. Rev Psiquiatr Rio Gd Sul. 2008;30:115-23.

17. Harwood D, Hawton K, Hope T, Jacoby R. Psychiatric disorder and personality factors associated with suicide in older people: a descriptive and case-control study. Int J Geriatr Psychiatry. 2001;16:155-65.

18. Conwell $Y$, Duberstein P. Suicide in older adults: determinants of risk and opportunities for prevention. In: Hawton $\mathrm{K}$, editor. Prevention and treatment of suicidal behaviour. New York: Oxford University; 2005. p. 221-37.

19. Chiu HF, Yip PS, Chi I. Elderly suicide in Hong Kong - a case controlled psychological autopsy study. Acta Psychiatr Scand. 2004;109:299-305.

20. Duberstein PR. Openness to experience and completed suicide across the second half of life. Int Psychogeriatr. 1995;7:183-98.

21. Waern M, Rubenowitz E, Runeson B. Burden of illness and suicide in elderly people: case-control study. BMJ. 2002;324:1355-7.

22. Harwood D, Howton K, Hope T. Life problems and physical illness as risk factors for suicide in older people: a descriptive and casecontrol study. Psychol Med. 2006;36:1265-74.

23. Mello-Santos C, Bertolote JM, Wang Y. Epidemiology of suicide in Brazil (1980-2000): characterization of age and gender rates of suicide. Rev Bras Psiquiatr. 2005;27:131-4.

24. Diekstra RF, Garnefski W. On the nature, magnitude and causality of suicidal behavior on international perspective. Suicide Life Threat Behav. 1995;25:36-57.

25. Marín-León L, Barros MB. Suicide mortality: gender and socioeconomic differences. Rev Saude Publica. 2003;37:357-63.

26. Santos SM, Barcellos C, Carvalho MS, Flores R. Detecção de aglomerados espaciais de óbitos por causas violentas em Porto Alegre, Rio Grande do Sul, Brasil, 1996. Cad Saude Publica. 2001;17:1141-51.

27. Meneghel SN, Victora CG, Faria NM, Carvalho LA, Falk JW. [Epidemiological aspects of suicide in Rio Grande do Sul, Brazil]. Rev Saude Publica. 2004;38:804-10.

28. Serrano AI. Impactos da modernidade sobre as pulsões autodestrutivas: ciências sociais e intervenção psiquiátrica [dissertation]. Florianópolis: Universidade Federal de Santa Catarina; 2003.

29. Jenkins CD. Injuries and violence. In: Building better health: a handbook of behavioral change. Washington: PAHO; 2009. p. 237-52. (Scientific and Technical Publication No. 590). http:// www.paho.org/English/DD/PUB/BBH_Injuries_Violence.pdf. Accessed 2011 May 21.

30. Chuang $\mathrm{H}$, Huang W. A reexamination of sociological and economic theories of suicide: a comparison of the USA and Taiwan. Soc Sci Med. 1996;43:421-3.

31. Minayo MC. A autoviolência, objeto da sociologia e problema de saúde pública. Cad Saude Publica. 1998;14:421-8.

32. Corrêa H, Barrero SP. Suicídio: uma morte inevitável. Rio de Janeiro: Atheneu; 2006.

\section{Correspondence}

Priscyla Waleska Targino de Azevedo Simões

Avenida Universitária, 1105 - Curso de Medicina, Bairro Universitário 88806-000 - Criciúma, SC - Brazil

E-mail: pri@unesc.net 